\title{
INDEKS KINERJA PERBANKAN SYARIAH DI ASIA TENGGARA BERDASARKAN KONSEP MAQÂSHID AL-SYARÎ'AH
}

\author{
Herni Ali HT'1 \& Ali Rama² \\ 1,2Universitas Islam Negeri (UIN) Syarif Hidayatullah Jakarta \\ Jl. Ir. H. Juanda No.95, Ciputat Jakarta 15412 Indonesia \\ E-mail: 1herni.ali@uinjkt.ac.id, 2rama@uinjkt.ac.id
}

\begin{abstract}
Sharia Banking Performance Index in Southeast Asia Based on the Concept of Maqâshid al-Syarî'ah. Islamic banks as a banking system that carries out Islamic vision in the field of finance and economics should develop a method of measuring performance in accordance with its vision. The vision of Islamic banks can be derived from the vision that chills reversed from the laws of sharia which is called maqâshid al-syarîah. Therefore, this study intends to develop methods of measuring the performance of Islamic banking based on the skill maqâshid al-syarî̀ah. The maqâshid al-syarî̀ah index is an index based on the three main visions of sharia banks, namely individual education (ta'dîb al-fard), justice enforcement (iqâmah al'adl) and welfare encouragement (jalb al-maslâhah). From the vision (dimension) is derived into indicators that are relevant and measurable. This research uses indexing method in calculating maqâshid al-syarîa index with case studies of sharia banking that has been operating in Southeast Asia covering Indonesia, Malaysia, Brunei Darussalam, Singapore, Thailand and Philippines. This study found that the majority of sharia banks in Southeast Asia have a low-performance maqâshid al-syarîah index. This shows that sharia banking is generally still run based on conventional vision even though it has operated in accordance with sharia principles or sharia compliance.
\end{abstract}

Keywords: maqâshid al-syarî̀ah, financial performance, justice, Islamic banks.

\begin{abstract}
Abstrak: Indeks Kinerja Perbankan Syariah di Asia Tenggara Berdasarkan Konsep Maqâshid al-Syarî̀ah. Bank syariah sebagai sistem perbankan yang menjalankan visi Islam dalam bidang keuangan dan ekonomi seharusnya mengembangkan metode pengukuran kinerja yang sesuai dengan visi yang diembannya. Visi bank syariah dapat diturunkan dari visi yang dinginkan dibalik dari hukum-hukum syariah yang biasa disebut maqâshid al-syarî̀ah. Oleh karena itu, penelitian ini bermaksud mengembangkan metode pengukuran kinerja perbankan syariah berdasarkan kerangka maqâshid al-syarî̀ah. Indeks maqâshid al-syarî̀ah adalah indeks yang didasarkan pada tiga visi utama bank syariah, yaitu pendidikan individu (ta'dîb al-fard), penegakan keadilan (iqâmah al-`adl) dan mendorong kesejahteraan (jalb al-maslâhah). Dari visi (dimensi) tersebut diturunkan ke dalam indikator-indikator yang relevan dan terukur. Penelitian ini menggunakan metode indeksasi dalam menghitung indeks maqâshid al-syarîah dengan studi kasus perbankan syariah yang telah beroperasi di Asia Tenggara meliputi Indonesia, Malaysia, Brunei Darussalam, Singapura, Thailand dan Filipina. Penelitian ini menemukan bahwa mayoritas bank syariah di Asia Tenggara memiliki kinerja indeks maqâshid al-syarîa h yang rendah. Hal ini menunjukkan bahwa perbankan syariah umumnya masih dijalankan berdasarkan pada visi konvensional meskipun sudah beroperasi sesuai dengan prinsip syariah atau sharia compliance.
\end{abstract}

Kata kunci: maqâshid al-syarîah, kinerja keuangan, keadilan, bank syariah.

\section{Pendahuluan}

Tidak bisa dipungkiri bahwa kawasan Asia Tenggara saat ini telah berkembang menjadi pusat perkembangan industri keuangan dan perbankan syariah di dunia. Indonesia dan Malaysia menjadi salah satu negara yang menjadi penggerak industri tersebut di kawasan. Thomson Reuters pada tahun 2014 mempublikasikan laporan perkembangan keuangan syariah global dengan menggunakan 8 indikator utama, yaitu lembaga keuangan syariah, tata kelola syariah, tata kelola perusahaan, pendidikan, penelitian, regulasi dan 
kesadaran keuangan syariah, telah menempatkan Malaysia sebagai peraih skor tertinggi, sementara Indonesia menempati peringkat ke-12'. Misalnya pada sektor perbankan syariah, total aset bank syariah di Malaysia telah mencapai sekitar USD 170,280 juta, sementara Indonesia sekitar USD 19,169 juta ${ }^{2}$

Perbankan syariah di kawasan Asia Tenggara tidak hanya berkembang di kedua negara tersebut, tetapi juga berkembang di Singapura, Brunei, Thailand dan Filipina. Singapura misalnya, pada bulan November 2004, Menteri Senior Goh Chok Tong berjanji untuk meningkatkan status Singapura sebagai Pusat Jasa Keuangan Syariah (Center for Islamic Financial Services). Ambisi ini tidak mustahil untuk dicapai mengingat negara tersebut memiliki sistem keuangan yang terbaik di dunia selain London3. Namun disadari bahwa perkembangan perbankan syariah di negaranegara Asia Tenggara tidak memiliki kualitas perkembangan yang sama, terdapat jarak perkembangan yang cukup signifikan. Tentunya ini tidak terlepas dari political will dari masingmasing negara tersebut untuk mengembangkan industri perbankan syariah di negaranya masingmasing. Kesenjangan perkembangan ini misalnya dapat terjadi disebabkan dukungan peraturan terhadap industri tersebut di masing-masing yurisdiksi ${ }^{4}$. Kesenjangan kualitas perkembangan ini tentunya berimplikasi pada kendala dalam terciptanya integrasi sistem keuangan di Asia Tenggara sebagai bagian dari integrasi ekonomi Asia Tenggara yang disebut sebagai Masyarakat Ekonomi ASEAN (MEA).

Perkembangan industri perbankan syariah yang cukup signifikan tentunya menyisakan satu pertanyaan serius; apa sebenarnya tujuan utama yang ingin dicapai oleh bank syariah? Apakah tujuan utamanya tidak jauh berbeda dengan entitas bisnis lainnya, yaitu untuk menciptakan

\footnotetext{
${ }^{1}$ Ali Rama, “Potensi Ekonomi Syariah Global," Republika, tanggal 24 November 2014, h.6.

2 lihat laporan The islamic Financial Services Board (IFSB), tahun 2015, h. 10

3 Ali Rama, "Analisis Deskriptif Perkembangan Perbankan Syariah di Asia Tenggara," Journal of Tauhidinomics, Vol. 1, No. 1, 2015, h. 17.

4 Ali Rama, "Analisis Sistem Tata Kelola Syariah Bagi Perbankan Syariah Di Indonesia Dan Malaysia," Jurnal Bimas Islam, Vol. 8, No. 1, 2015, h. 95.
}

nilai tambah khususnya keuntungan material bagi pemilik modalnya (shareholders) ${ }^{5}$. Perbedaan utama sistem perbankan syariah dengan bank konvensional tidak hanya terletak pada cara bagaimana bisnisnya dilakukan, tetapi di atas itu semua terletak pada nilai-nilai yang mendasari bank syariah pada keseluruhan operasi dan visinya ${ }^{6}$. Nilai-nilai tersebut tidak hanya terefleksikan pada transaksi-transaksinya tetapi terletak pada peranannya untuk mewujudkan tercapainya tujuantujuan syariah (maqâshid al-syarî̀ah)7.

Perbankan dan keuangan syariah menurut Laldin dan Furqan ${ }^{8}$ didirikan dengan tujuan untuk membawa visi Islam dalam bidang ekonomi ke dalam lingkungan perbankan dan keuangan dengan maksud merealisasikan kesejahteraan manusia (maslahah) dan keadilan di tengah masyarakat. Praktik keuangan syariah seharusnya dikelola dengan maksud untuk mencapai tujuan tersebut. Desain tujuan bank syariah seharusnya sama dengan tujuan yang ingin dicapai oleh syariah atau biasa disebut maqâshid al-syarî̀ah. ${ }^{9}$ Sebagaimana dikatakan oleh Rama dan Makhlani ${ }^{10}$ bahwa bank syariah dibentuk sebagai mekanisme untuk mencapai tujuan-tujuan syariah di bidang muamalat terutama terkait dengan aktivitas dan transaksi keuangan.

Dengan sistem operasional dan visi yang berbeda tentunya, metode pengukuran kinerja yang diterapkan pada sistem perbankan syariah seharusnya dapat mengakomodir tujuan utama tersebut. Rasio-rasio keuangan yang bersifat maksimalisasi nilai tambah bagi pemilik modal seharusnya tidak menjadi kerangka utama dalam

\footnotetext{
${ }^{5}$ Omar Mustafa dan A. Dzuljastri Razak, "The Performance Measures of Islamic Banking Based on the Maqashid Framework," pada IIUM International Accounting Conference, 2008, h. 4.

6 Ali Rama, "Analisis Kerangka Regulasi Model Shariah Governance," Journal of Islamic Economics Lariba, Vol. 1, No. 1, 2015, h. 13.

7 Asyraf Wajdi Dusuki dan Nurdianawati Irwani Abdullah, "Why Do Malaysian Customers Patronise Islamic Banks?," International Journal of Bank Marketing, Vol. 25, No. 3, 2007, h.145.

${ }^{8}$ Mohamad Akram Laldin dan Hafas Furqani, "Developing Islamic Finance in the Framework of Maqasid Al-Shari'ah," International Journal of Islamic and Middle Eastern Finance and Management, Vol. 6, No. 4, 2013, h. 280.

${ }^{9}$ Herni HT Ali dan Ali Rama, "Peringkat Kinerja Lembaga Keuangan Syariah Berdasarkan Maqashid Syariah,” Dialog, Vol. 39, No. 2, 2016, h. 145.

${ }^{10}$ Ali Rama dan Makhlani, “Pembangunan Ekonomi Dalam Tinjauan Maqashid Syariah,” Dialog, Vol. 1, No. 1, 2013, h. 36.
} 
penilaian ketercapaian kinerja suatu bank syariah. Obaidullah, ${ }^{11}$ misalnya, mengajukan kinerja aspek etika dan sosial yang harus menjadi alat ukur kinerja bagi sebuah bank syariah. Metode ini sebenarnya tidak jauh berbeda dengan apa yang sudah dikembangkan di Barat dengan konsep 'ethical values' dan 'corporate social responsibility' nya. Konsep ini didasari pada nilai budaya dan agama orang Barat berdasarkan paham rasionalitas (rasionalism).

Di sisi lain, terdapat beberapa metode pengukuran kinerja perbankan syariah diajukan didasarkan pada keterpenuhan terhadap syariah. Pada aspek kepedulian sosial, di antaranya misalnya, Rama dan Meliana'2 dan Dusuki dan Irwani'³melakukan metode indeks yang diambil dari konsep-konsep syariah sebagai indikator penilaian kinerja bank syariah pada aspek kepedulian sosial. Ali dan Rama ${ }^{14}$ juga mendesain model pengukuran kinerja bank syariah dengan menggunakan indeks maqâshid al-syarîaah sebagai cara untuk melihat sejauh mana bank syariah mencapai tujuan-tujuan syariah dalam pengelolaan bisnisnya.

Berdasarkan pada latar belakang tersebut, penelitian ini bermaksud untuk mengukur kinerja perbankan syariah di sejumlah negara di Asia Tenggara dalam hal pencapaian dan penguatan tiga tujuan utama yang diinginkan oleh syariah. Konsep ini selanjutnya menghasilkan peringkat kinerja perbankan syariah di negara-negara tersebut.

Adapun sistematika dari penelitian ini adalah dimulai dengan latar belakang di bagian pertama. Kajian konsep dan pustaka dilakukan di bagian kedua, dan selanjutnya penjelasan metodologi pada bagian selanjutnya. Bagian keempat menampilkan hasil dan analisisnya lalu ditutup dengan kesimpulan dan rekomendasi.

"Mohamad Obaidullah "Rating of Islamic Financial Institutions Some Methodological Suggestions," Working Paper, IRTI Jedah, 2005, h.11.

12 Ali Rama dan Meliawati, "Analisis Determinan Pengungkapan Islamic Social Reporting: Studi Kasus Bank Umum Syariah Di Indonesia," EQUILIBRIUM: Jurnal Ekonomi Syariah, Vol. 2, No. 1, 2014, h. 95-115.

${ }^{13}$ Asyraf Wajdi Dusuki dan Abdullah Nurdianawati Irwani, "Maslahah and Corporate Social Responsibility," The American Journal of Islamic Social Science, Vol. 24, No. 1, 2005, h. 25-42.

${ }^{14}$ Herni Ali HT dan Rama, "Peringkat Kinerja Lembaga..., h.145.

\section{Kajian Konsep Maqâshid al-Syarî̀ah}

Konsep maqâshid al-syarî̀ah sebenarnya telah dimulai dari masa al-Juwaini yang terkenal dengan Imam Haramain dan oleh Imam al-Ghazâli kemudian disusun secara sistematis oleh seorang ahli ushul fikih bermazhab Maliki dari Granada (Spanyol), yaitu Imam al-Syâthibî. Konsep itu ditulis dalam kitabnya yang terkenal, al-Muwâfaqat fî Ushul al-Ahkâm, khususnya pada juz II, yang beliau namakan kitab al-Maqâshid. Menurut alSyatibi, pada dasarnya syariat ditetapkan untuk mewujudkan kemaslahatan hamba (mashâlih al-`ibâd), baik di dunia maupun di akhirat. Kemaslahatan inilah, dalam pandangan beliau, menjadi maqâshid al-syarîah . Dengan kata lain, penetapan syari'at, baik secara keseluruhan (jumlatan) maupun secara rinci (tafshîlan), didasarkan pada suatu 'illat (motif penetapan hukum), yaitu mewujudkan kemaslahatan hamba.

Maqâshid al-syarî̀ah jika ditinjau dari makna katanya dapat diartikan sebagai tujuan (maqâshid) yang ingin dicapai dibalik dari hukum-hukum Allah (syariah) yang ditetapkan untuk manusia agar dipedomanin dalam mencapi kebahagian dunia dan akhirat. Dengan demikian, maqâshid al-syarî̀ah berarti kandungan nilai yang menjadi tujuan pensyariatan hukum. ${ }^{15}$

Sementara itu, Wahbah al-Zuhailîí mendefinisikan maqâshid al-syarîah sebagai nilai-nilai dan sasaran syara' yang tersirat dalam segenap atau sebagian terbesar dari hukum-hukumnya, atau tujuan akhir dari syariat dan rahasia-rahasia yang diletakkan oleh syara' pada setiap hukumnya. Selanjutnya, Yusuf al-Qardhâwi ${ }^{17}$ mendefinisikan maqâshid al-syarîah sebagai tujuan yang menjadi target teks dan hukum-hukum partikular untuk direalisasikan dalam kehidupan manusia baik berupa perintah, larangan, dan mubah untuk individu, keluarga, jamaah, dan umat, atau juga disebut dengan hikmah-hikmah yang menjadi tujuan ditetapkannya hukum, baik yang diharuskan ataupun tidak. Setiap hukum yang disyariatkan

15 Ghofar Shidiq, “Teori Maqashid Al-Syari'ah Dalam Hukum Islam," Sultan Agung, Vol. XIV, No. 1, 2009, h. 119.

${ }^{16}$ Wahbah al-Zuhaili, Ushul Al-Fiqh Al-Islami, (Beirut: Dar al-Fikr, 1986), h.1017.

17 Yusuf Qardhawi, Fiqh Maqashid Syariah, (Jakarta: Pustaka al-Kautsar, 2007), h. 7. 
kepada tiap hambanya pasti ada kandungan hikmahnya, yaitu tujuan luhur di balik kandungan hukum tersebut.

Maqâshid al-syarîaah di kalangan ulama usul fikih disebut sebagai asrâr al-syarîah, yaitu rahasia-rahasia yang terdapat di balik hukum yang ditetapkan oleh syara', berupa kemaslahatan bagi manusia, baik di dunia maupun di akhirat. Karena itu, Imam al-Ghazâli dan al-Syathibî merinci lima unsur pokok yang menjadi tujuan syariat yaitu pemeliharaan agama (dîn), nyawa (nafs), akal ('aql), keturunan (nasl) dan harta (mâl). Menurut al-Ghazâlî, tujuan utama syariah adalah untuk melayani kepentingan manusia dan untuk menjaga mereka dari segala sesuatu yang mengancam eksistensinya. la selanjutnya mengklasifikasikan maqâshid (tujuan) ke dalam empat pembagian utama, yaitu dengan mengatakan: ${ }^{18}$

"The very objective of the Shariah is to promote the well-being of thepeople, which lies in safeguarding their faith (din), their self (nafs), their intellect ( $a q l)$, their posterity (nasl), and their wealth (mal). Whatever ensures the safeguard of these five serves public interest and is desirable, and whatever hurts them is against public interest and its removal is desirable."

Dari sini, dengan jelas al-Ghazâlî mengungkapkan bahwa tujuan utama dari syariah adalah untuk mendorong kemaslahatan (kesejahteraan) manusia yang mana terletak pada pemeliharaan agama, hidup, akal, keturunan dan kekayaan. Selanjutnya, segala sesuatu yang melindung lima unsur kepentingan publik tersebut maka dianjurkan dilakukan. Dan sebaliknya, segala sesuatu yang mengancamnya adalah harus dihilangkan.

Pandangan yang relatif berbeda tentang tujuan-tujuan yang ingin dicapai dibalik dari hukum-hukum Allah dikemukakan oleh Abû Zaharah, ${ }^{19}$ yaitu bahwa maqâshid al-syarî̀ah dibagi menjadi tiga tujuan utama yang ingin dicapai meliputi (i) pendidikan individu (ta'dîb al-fard); (ii) penegakan keadilan (iqâmah al-'adl); dan (iii) mendorong kesejahteraan (jalb al-maslâhah).

${ }^{18}$ Umar Chapra, The Islamic Vision of Development in the Light of Maqasid Al-Shariah, (IDB, 2008), h.4.

${ }^{19}$ Abu Zaharah, Ushulul Figh, (Mesir: Dar el-Fikri al Arabi, 1958), h. 89 .

\section{Studi Terdahulu mengenai Maqâshid al-Syarî̀ah sebagai Model Pengukuran Kinerja}

Penelitian ini bermaksud untuk mengukur kinerja lembaga keuangan syariah di sejumlah negara Asia Tenggara, yaitu Indonesia, Singapura, Malaysia, Brunei Darussalam, Thailand dan Filipina dengan menggunakan pendekatan indeks maqâshid al-syarîah. Berdasarkan pada indeks tersebut maka akan ditampilkan kinerja masingmasing bank syariah di negara-negara tersebut. Adapun uraian metodologi yang dikembangkan dalam penelitian diuraikan sebagai berikut:

\section{Jenis dan Sumber Data}

Sumber utama data yang digunakan dalam penelitian ini berasal dari data sekunder, yaitu berupa laporan keuangan yang dipublikasikan secara resmi dan berkala di masing-masing website bank syariah yang menjadi objek dalam penelitian ini. Data sekunder yang digunakan dari tahun 2013 sampai 2015. Data sekunder tersebut dikumpulkan dan diolah berdasarkan kepentingan dan tujuan penelitian. Adapun variabel yang digunakan dalam penelitian dapat dilihat pada Tabel 2. Adapun konsep operasionalisasi konsep sampai ke variabel dijelaskan pada bagian selanjutnya.

Selanjutnya, negara yang menjadi objek penelitian di Asia Tenggara hanya enam negara saja, yaitu Indonesia, Malaysia, Singapura, Brunei Darussalam, Thailand dan Filipina. Negara tersebut dipilih dikarenakan adanya bank syariah yang beroperasi di negara-negara tersebut. Sementara negara Asia Tenggara lainnya belum memiliki bank syariah.

\section{Sampel dan Populasi}

Sebagaimana dijelaskan sebelumnya bahwa penelitian ini bermaksud untuk mengukur kinerja bank syariah dengan menggunakan pendekatan indeks maqâshid al-syarîaah maka penelitian ini selanjutnya memilih sejumlah bank syariah yang telah beroperasi di negara-negara Asia Tenggara. Penelitian ini hanya membatasi sejumlah bank syariah yang ada di negara-negara objek penelitian dikarenakan terdapat sejumlah bank syariah di negara-negara tersebut yang tidak menyediakan laporan keuangan yang lengkap. Akibatnya, bank 
tersebut tidak bisa dilakukan pengukuran kinerja. Adapun bank syariah yang dijadikan sampel dalam penelitian ini yang tersebar di masing-masing negaranegara objek penelitian dapat dilihat pada Tabel 1.

Bank syariah yang ditampilkan pada Tabel 1 sebenarnya sudah merepresentasikan perbankan syariah di masing-masing negara tersebut. Penelitian ini menggunakan sampel bank syariah di Indonesia dan Malaysia lebih banyak dibandingkan dengan negara lain disebabkan kedua negara tersebut pada kenyataannya menjadi negara yang paling menonjol dan dominan dalam pengembangan bank syariah di Asia Tenggara. Kedua negara tersebut juga menjadi negara yang paling banyak memiliki bank syariah.

Tabel 1: Bank Syariah di Asia Tenggara

\begin{tabular}{|c|c|}
\hline Indonesia & Malaysia \\
\hline 1. Bank Mandiri Syariah & 1. Affin Islamic Bank Berhard \\
\hline 2. Bank Mega Syariah & 2. Asian Finance Bank Berhard \\
\hline $\begin{array}{l}\text { 3. Bank Muamalat } \\
\text { Indonesia }\end{array}$ & $\begin{array}{l}\text { 3. HSBC Amanah Malaysia } \\
\text { Berhard }\end{array}$ \\
\hline 4. Bank Victoria Syariah & 4. Standard Chartered Saadiq \\
\hline 5. Bank BCA Syariah & Bank Berhard \\
\hline 6. Bank BRI Syariah & 5. AM Islamic Bank Berhard \\
\hline $\begin{array}{l}\text { 7. Bank Maybank Syariah } \\
\text { Indonesia }\end{array}$ & $\begin{array}{l}\text { 6. Al Rajhi Banking \& } \\
\text { Ivestment (Malaysia) }\end{array}$ \\
\hline 8. Bank Panin Syariah & Berhard \\
\hline 9. Bank Bukopin Syariah & 7. CIMB Islamic Bank \\
\hline 10. Bank BNI Syariah & 8. RHB Islamic Bank \\
\hline 11. Bank BJB Syariah & 9. Bank Islam Malaysia \\
\hline & 10. OCBC Al-Amin Bank Berhard \\
\hline & $\begin{array}{l}\text { 11. Hong Leong Islamic Bank } \\
\text { berhard }\end{array}$ \\
\hline & 12. Bank Muamalat Malaysia \\
\hline Filipina & Singapura \\
\hline 1. Amanah Islamic & 1. Noor Islamic Bank \\
\hline $\begin{array}{l}\text { Invesment Bank of } \\
\text { Philippines }\end{array}$ & 2. Maybank Islamic Bank \\
\hline Thailand & Brunei Darussalam \\
\hline $\begin{array}{l}\text { 1. Islamic Bank of } \\
\text { Thailand }\end{array}$ & $\begin{array}{l}\text { 1. Bank Islam Brunei } \\
\text { Darussalam Berhard }\end{array}$ \\
\hline
\end{tabular}

\section{Operasionalisasi Konsep}

Konsep operasionalisasi konsep yang diadopsi dari penelitian ini merupakan pengembangan dari model penelitian Herni dan Rama ${ }^{20}$ sebelumnya. Perbedaan utama dengan penelitian ini adalah pada luas cakupan objek penelitiannya yang membandingkan dengan sejumlah negara di Asia Tenggara. Penelitian ini tentunya mampu menampilkan keunikan dari kinerja indeks maqâshid al-syarî̀ah di negara Asia Tenggara yang tidak

20 Herni Ali dan Ali Rama, "Peringkat Kinerja Lembaga Keuangan Syariah Berdasarkan Maqashid Syariah.” Dialog Vol. 39, No. 2, 2016, h. 145. ditampilkan oleh penelitian sebelumnya. Negara yang memiliki sistem regulasi yang lebih baik tentunya punya dampak pada kinerja inetrnal perbankan syariah yang beroperasi di negara tersebut.

Konsep indeks maqâshid al-syarîah yang selanjutnya disebut indeks MS diturunkan dari kerangka maqâshid al-syarîah yaitu (i) pendidikan individu (ta'dîb al-fard); (ii) penegakan keadilan (iqâmah al-'adl); dan (iii) mendorong kesejahteraan (jalb al-maslâhah). Selanjutnya, masing-masing dimensi tersebut diderivasikan menjadi elemenelemen terukur dan terkecil. Setelah dilakukan operasionalisasi konsep, selanjutnya dilakukan pembobotan untuk menemukan nilai komposit indeks untuk masing-masing dimensi dan kategori. Operasionalisasi konsep MS ke dalam indikatorindikator terukur dalam konteks perbankan syariah dapat dilihat pada Tabel 2. Indikatorindikator tersebut dapat dijadikan sebagai alat ukur penilaian kinerja perbankan syariah dalam pencapaian tujuan berdasarkan pada konsep MS.

Tabel 2: Operasional Kerangka Maqâshid al-syarîaah pada Perbankan Syariah

\begin{tabular}{|c|c|c|c|}
\hline $\begin{array}{c}\text { Konsep } \\
\text { Maqâshid } \\
\text { al-syarîah }\end{array}$ & Elemen (E) & Indikator (I) & Variabel (V) \\
\hline \multirow[t]{4}{*}{$\begin{array}{l}\text { Pendidikan } \\
\text { Individu } \\
\text { (educating } \\
\text { individual) } \\
\text { D1 }\end{array}$} & $\begin{array}{l}\text { Peningkatan } \\
\text { Pengetahuan }\end{array}$ & $\begin{array}{l}\text { Biaya } \\
\text { pendidikan }\end{array}$ & $\begin{array}{l}\text { Biaya } \\
\text { pendidikan/ } \\
\text { total } \\
\text { pendapatan }\end{array}$ \\
\hline & & Riset & $\begin{array}{l}\text { Pengeluaran } \\
\text { riset/total } \\
\text { pengeluaran }\end{array}$ \\
\hline & $\begin{array}{l}\text { Pengembangan } \\
\text { skill baru dan } \\
\text { perbaikan }\end{array}$ & Training & $\begin{array}{l}\text { Pengeluaran } \\
\text { training/total } \\
\text { pengeluaran }\end{array}$ \\
\hline & $\begin{array}{l}\text { Menciptakan } \\
\text { kesadaran } \\
\text { terhadap } \\
\text { perbankan } \\
\text { syariah }\end{array}$ & Publikasi & $\begin{array}{l}\text { Pengeluaran } \\
\text { publikasi/ } \\
\text { total } \\
\text { pengeluaran }\end{array}$ \\
\hline \multirow{3}{*}{$\begin{array}{l}\text { Mewujudkan } \\
\text { keadilan } \\
\text { (establishing } \\
\text { justice) } \\
\text { D2 }\end{array}$} & $\begin{array}{l}\text { Keadilan } \\
\text { dalam kontrak/ } \\
\text { transaksi }\end{array}$ & $\begin{array}{l}\text { Bagi hasil } \\
\text { yang adil }\end{array}$ & $\begin{array}{l}\text { Keuntungan/ } \\
\text { total } \\
\text { pendapatan }\end{array}$ \\
\hline & $\begin{array}{l}\text { Produk dan } \\
\text { layanan yang } \\
\text { terjangkau }\end{array}$ & $\begin{array}{l}\text { Harga yang } \\
\text { terjangkau }\end{array}$ & $\begin{array}{l}\text { Utang } \\
\text { bermasalah/ } \\
\text { total } \\
\text { investasi }\end{array}$ \\
\hline & $\begin{array}{l}\text { Penghilangan } \\
\text { ketidakadilan }\end{array}$ & $\begin{array}{l}\text { Produk tanpa } \\
\text { bunga }\end{array}$ & $\begin{array}{l}\text { Pendapatan } \\
\text { bebas } \\
\text { bunga/total } \\
\text { pendapatan }\end{array}$ \\
\hline
\end{tabular}




\begin{tabular}{clll}
\hline $\begin{array}{c}\text { Mendorong } \\
\text { kesejahteraan } \\
\text { (public } \\
\text { interest) } \\
\text { D3 }\end{array}$ & Keuntungan & $\begin{array}{l}\text { Rasio } \\
\text { keuntungan }\end{array}$ & $\begin{array}{l}\text { Keuntungan } \\
\text { bersih/total } \\
\text { aset }\end{array}$ \\
\hline & $\begin{array}{l}\text { Distribusi } \\
\text { pendapatan } \\
\text { dan kekayaan }\end{array}$ & $\begin{array}{l}\text { Pendapatan } \\
\text { personal }\end{array}$ & $\begin{array}{l}\text { Zakat/ } \\
\text { pendapatan } \\
\text { bersih }\end{array}$ \\
\hline & $\begin{array}{l}\text { Investasi pada } \\
\text { sektor strategis }\end{array}$ & $\begin{array}{l}\text { Rasio } \\
\text { investasi } \\
\text { pada sektor } \\
\text { riil }\end{array}$ & $\begin{array}{l}\text { Deposito } \\
\text { investasi/total } \\
\text { deposito }\end{array}$ \\
& & & \\
\hline
\end{tabular}

Adaptasi dari Herni dan Rama (2015)

\section{a. Pendidikan Individu (ta'dîb al-fard)}

Tujuan pertama dari syariah (maqashid syariah) yang dikembangkan menjadi konsep tujuan dalam penelitian ini adalah peningkatan pendidikan individu. Bank syariah memiliki misi untuk selalu meningkatkan pendidikan individu (pegawai) begitu pula dengan masyarakat secara umum. Adapun dimensi, elemen serta indikator dari tujuan pertama (maqashid syariah) ini dalam konteks pengukuran kinerja perbankan syariah adalah:

\section{a) Peningkatan pengetahuan}

Bank syariah sebagai lembaga keuangan yang menawarkan produk dan layanan sesuai prinsip syariah harus memiliki misi untuk mengembangkan pengetahuan bagi para pegawainya begitu pula dengan masyarakat secara umum. Misi ini dapat diukur melalui dua elemen, yaitu seberapa besar biaya pendidikan dan biaya riset yang dialokasikan oleh bank syariah. Indikator terukur dari elemen ini adalah rasio biaya pendidikan terhadap total pengeluaran dan rasio biaya riset terhadap total pengeluaran. Dengan demikian, diasumsikan bahwa semakin tinggi rasio indikator maka bank syariah memiliki perhatian yang tinggi terhadap pengembangan pengetahuan.

b) Pengembangan skill baru dan perbaikan

Bank syariah memiliki kewajiban untuk menyediakan sejumlah alokasi anggaran demi mengupgrade kemampuan maupun skill para pegawainya. Hal ini dapat terlihat pada sejumlah dana yang dialokasikan untuk mengikutkan para pegawainya dalam kegiatan pelatihan dan training pegawai. Adapun indikator terukur dari elemen ini adalah rasio biaya pelatihan dan training terhadap total pengeluaran. Dengan demikian diasumsikan bahwa semakin besar rasio indikator maka semakin besar perhatian bank syariah terhadap peningkatan skill para pegawainya.

c) Meningkatkan kesadaran terhadap perbankan syariah

Salah satu misi yang harus diemban oleh bank syariah adalah meningkatkan kesadaran dan keberpihakan masyarakat kepada lembaga keuangan yang menawarkan produk dan layanan syariah. Sehingga masyarakat dapat beralih dari praktek keuangan konvensional ke praktik keuangan syariah. Salah satu bukti keterlibatan bank syariah dalam melakukan sosialisasi dan publisitas tentang produk dan layanan perbankan syariah kepada masyarakat adalah alokasi biaya publikasi dan promosi. Adapun indikator pengukurnya adalah rasio biaya publikasi dan promosi terhadap total biaya pengeluaran. Dengan demikian diasumsikan bahwa semakin tinggi rasio indikator maka semakin besar perhatian bank syariah terhadap peningkatan kesadaran masyarakat terhadap produk dan layanan yang sesuai dengan syariah

\section{b. Penegakan Keadilan (iqâmah al-'adl)}

Tujuan kedua dari syariah (maqashid syariah) yang dikembangkan menjadi tujuan konsep dalam penelitian ini adalah menegakkan keadilan (iqâmah al-'adl). Bank syariah memiliki tujuan untuk menciptakan produk-produk keuangan yang terjangkau dan berbasiskan pada prinsip keadilan. Bank syariah tidak boleh memiliki produk yang didasarkan pada kontrak yang dapat merugikan salah satu pihak yang terlibat dalam kontrak. Dengan demikian bank syariah harus mengembangkan jenis produk yang didasarkan pada kontrak berbasis keadilan kepada semua pihak yang terlibat. Adapun dimensi, elemen dan indikator dari tujuan kedua (maqâshid al-syarîah) dalam konteks pengukuran kinerja bank syariah adalah:

a) Keadilan dalam kontrak dan transaksi

Bank syariah sudah seharusnya melakukan transaksi secara adil kepada nasabahnya. Oleh karena itu jenis kontrak yang di- 
kembangkan untuk mendukung transaksi keuangannya harus berdasarkan pada prinsip keadilan, tidak boleh ada salah satu pihak yang diuntungkan sementara pihak lainnya dirugikan. Jenis kontrak yang dianggap lebih adil dibandingkan dengan kontrak yang berbasis utang-berbunga adalah kontrak bagi hasil. Jenis kontrak yang didasarkan pada prinsip bagi hasil adalah kontrak musyârakah dan mudhârabah. Dengan demikian jumlah pembiayaan dalam bentuk kontrak musyârakah dan mudhârabah menjadi indikasi atas keberpihakan bank syariah terhadap tingkat bagi hasil yang adil. Adapun indikator pengukurnya adalah rasio pembiayaan musyarakah dan mudhârabah terhadap total dana syirkah. Semakin tinggi nilai rasio ini menunjukkan bahwa bank syariah menawarkan skema transaksi mudhârabah dan musyarakah yang tinggi sehingga menunjukkan bahwa bank syariah meningkatkan fungsinya untuk mewujudkan keadilan ekonomi melalui transaksi bagi hasil.

b) Produk dan layanan yang terjangkau Bank syariah yang memiliki produk dan layanan yang sesuai dengan prinsip syariah tentunya dituntut untuk menawarkan produkproduk yang terjangkau oleh para nasabah. Olehnya, harga produk bank syariah harus terjangkau. Adapun indikator yang digunakan dalam penelitian ini adalah rasio pembiayaan musyârakah dan mudhârabah terhadap total pembiayaan yang diberikan oleh bank syariah. Apabila rasio ini semakin meningkat, maka bank syariah memberikan pembiayaan yang tinggi kepada masyarakat dalam bentuk akad berbasis bagi hasil yang dapat dijangkau oleh masyarakat. Semakin banyak pembiayaan yang diberikan kepada nasabah (masyarakat) maka menunjukkan bahwa produk bank syariah dapat dijangkau oleh masyarakat.

c) Penghilangan produk dan transaksi yang tidak adil

Praktek riba atau umumnya dikenal sebagai suku bunga (interest rate) dalam transaksi keuangan di perbankan merupakan jenis transaksi yang tidak diperbolehkan pada bank syariah. Transaksi keuangan berbasis riba sudah menjadi praktek umum yang jamak dilakukan pada bank konvensional. Bank syariah tidak boleh menawarkan produk keuangan berdasarkan pada prinsip riba atau bunga. Hal ini dikarenakan riba atau transaksi keuangan yang ada unsur ribanya memiliki dampak negatif pada perekonomian dan menciptakan ketidakadilan dalam transaksi ekonomi. Sistem riba merupakan sistem yang memberikan peluang bagi para pemilik modal (orang kaya) untuk dapat mengeksploitasi orang miskin demi untuk mendapatkan untung yang besar atas kepemilikan dana yang besar. Oleh karena itu bank syariah diharuskan untuk menjalankan aktivitas perbankannya khususnya pada saat melakukan investasi dan pembiayaan tanpa ada unsur riba di dalamnya. Jika hal ini terwujud maka bank syariah berkontribusi dalam mengurangi tingkat kesenjangan pendapatan dalam masyarakat melalui transaksi perbankan bebas bunga. Elemen dari penghilangan produk dan transaksi yang tidak adil pada bank syariah adalah produk perbankan tanpa bunga. Adapun indikator terukurnya adalah rasio pendapatan non-bunga terhadap total pendapatan bank syariah. Semakin tinggi nilai rasio menunjukkan bank syariah memiliki struktur pendapatan yang didominasi dari pendapatan non-bunga. Berarti bank syariah memiliki komposisi pendapatan yang didominasi dari pendapatan non-bunga.

\section{c. Mendorong Kesejahteraan (jalb al-maslâhah)}

Tujuan ketiga dari syariah (maqâshid alsyarîah) yang dikembangkan dalam penelitian ini adalah terciptanya kesejahteraan (jalb almaslâhah). Kehadiran bank syariah di tengahtengah masyarakat dimaksudkan untuk dapat berkontribusi dalam meningkatkan kesejahteraan masyarakat secara umum. Banyak teori yang sudah membuktikan bahwa sektor perbankan berkontribusi dalam mendorong pertumbuhan ekonomi dengan fungsi intermediasi yang dilakukannya, yaitu mobilisasi dana dari masyarakat (surplus unit) yang selanjutnya dialokasikan kepada sektor usaha yang membutuhkan (deficit unit) demi melakukan kegiatan produksi. Bank syariah sebagai lembaga intermediasi tentunya 
harus menjalankan fungsinya demi mendorong peningkatan kesejahteraan masyarakat dan pertumbuhan ekonomi. Semakin banyak bank syariah yang beroperasi dalam perekonomian seharusnya semakin meningkat kesejahteraan masyarakat. Adapun dimensi, elemen dan indikator terukur dari tujuan ketiga maqashîd al-syarîah (T3) dalam konteks pengukuran kinerja bank syariah adalah:

a) Keuntungan

Keuntungan yang besar menjadi indikasi kesejahteraan yang semakin meningkat. Semakin tinggi keuntungan perusahaan berarti semakin banyak produksi yang dilakukan. Produksi yang banyak berarti masyarakat menikmati hasil produksi yang banyak dan beranekaragam. Di saat bersamaan, keuntungan yang tinggi akibat produksi yang meningkat akan meningkatkan pendapatan rumah tangga sebagai pemilik faktor produksi. llustrasi ini tidak jauh berbeda dengan aktivitas perbankan. Semakin tinggi keuntungan bank maka semakin banyak dana yang diakses oleh masyarakat dari perbankan begitu pula dengan pendapatan para stakeholdernya. Dengan demikian bank syariah dituntut untuk meningkatkan keuntungannya demi peningkatan kesejahteraan masyarakat. Dengan demikian rasio keuntungan menjadi indikator tingkat keuntungan bank syariah. Adapun indikator terukur dari keuntungan bank syariah adalah rasio keuntungan bersih terhadap total aset. Semakin tinggi nilai rasio, semakin tinggi kesejahteraan para stakeholder bank syariah, seperti pemilik, pegawai, nasabah, masyarakat, pemerintah dan pihak lainnya.

b) Distribusi pendapatan dan kekayaan

Fungsi utama perbankan baik syariah maupun konvensional adalah intermediasi keuangan, yaitu mobilisasi dan alokasi dana. Fungsi ini berkontribusi dalam menciptakan distribusi dan penyebaran kekayaan kepada semua elemen masyarakat. Dengan demikian, bank syariah memiliki peran penting dalam menciptakan distribusi pendapatan dan kekayaan yang merata kepada semua golongan. Hal ini dapat terlihat pada alokasi dana zakat yang diberikan bank syariah kepada orangorang yang membutuhkan. Dana zakat yang didistribusikan menjadi instrumen yang cukup efektif dalam menciptakan keseimbangan dan pemerataan ekonomi. Tingkat Pendapatan bersih perusahaan menjadi representasi dari dimensi. Adapun indikator terukur yang dapat dilakukan untuk melihat tingkat kontribusi bank syariah pada distribusi pendapatan dan kekayaan adalah melalui rasio jumlah zakat yang dikeluarkan terhadap pendapatan bersih bank syariah. Semakin tinggi nilai rasio, semakin tinggi dana zakat yang dikeluarkan oleh bank syariah. Rasio yang tinggi tersebut menunjukkan bahwa bank syariah berkontribusi dalam meningkatkan pendapatan orang-orang yang lemah seperti kaum fakir dan miskin. Sehingga kesejahteraan mereka juga mengalami peningkatan.

c) Investasi pada sektor strategis

Salah satu bentuk distingsi bank syariah terhadap bank konvensional adalah keberpihakannya terhadap sektor riil dan strategis yang menyangkut kehidupan banyak. Dalam artian bank syariah memiliki perhatian yang tinggi terhadap pembiayaan sektor riil dan strategis. Sektor ini menjadi perhatian utama dikarenakan sektor ini menjadi penggerak utama perekonomian masyarakat dan tentunya juga menjadi sektor yang terkait langsung dengan kebutuhan dasar masyarakat. Sektor-sektor yang dimaksud, misalnya, adalah sektor pertanian, air dan listrik, konstruksi, pertambangan dan usaha mikro. Untuk melihat seberapa besar partisipasi bank syariah terhadap investasi sektor riil digunakan rasio investasi sektor riil. Adapun indikatornya adalah rasio investasi sektor riil terhadap total dana syirkah. Semakin tinggi nilai rasio ini menunjukkan bahwa bank syariah melakukan alokasi pembiayaan yang tinggi terhadap sektor riil dan strategis yang terkait langsung dengan kebutuhan masyarakat. Rasio yang semakin tinggi menunjukkan bahwa bank syariah meningkatkan kesejahteraan masyarakat.

\section{Metode Analisis}

Metode penghitungan indeks maqâshid al-syarîah yang digunakan dalam penelitian 
ini mengadopsi studi-studi sebelumnya yang menggunakan metode indeksasi seperti Anto, ${ }^{21}$ Herni dan Rama ${ }^{22}$ dan Omar dan Razak. ${ }^{23}$ Adapun langkah-langkahnya sebagai berikut: Pertama, data yang bernilai negatif terlebih dahulu di positifkan, yaitu jika basis datanya desimal maka 1 - nilai aktual. Contoh variabel yang bernilai negatif pada penelitian ini adalah rasio utang bermasalah terhadap total investasi pada dimensi keadilan (lihat Tabel 2). Jika data sudah sama basisnya semua (positif) maka langkah kedua adalah menghitung indeks untuk masing-masing indikator dengan menggunakan pendekatan nilai maksimum dan minimum. Adapun formulanya adalah sebagai berikut:

$$
\text { Indeks }=\frac{\text { nilai aktual—nilai } \min }{\text { nilai maks—nilai } \min }
$$

Nilai aktual adalah nilai/angka yang terjadi pada indikator di masing-masing bank syariah yang diteliti. Sementara nilai maks dan min adalah nilai maksimum dan minimum pada pada data yang diolah. Ketiga, setelah mendapatkan nilai dengan pendekatan maksimum dan minimum, metode rata-rata hitung selanjutnya digunakan untuk menemukan nilai indikator maupun elemen. Adapun formula dari ketiga elemen penelitian adalah sebagai berikut:

$$
\begin{aligned}
& D_{1 \text { (pendidikan) }}=1 / 3\left(E_{1}+E_{2}+E_{3}\right) \\
& D_{2(\text { keadialan })}=1 / 3\left(E_{1}+E_{2}+E_{3}\right) \ldots \\
& D_{3 \text { (kesejahteraan) }}=1 / 3\left(E_{1}+E_{2}+E_{3}\right) \ldots
\end{aligned}
$$

Adapun $\mathrm{D}$ adalah dimensi. Dimensi yang dimaksud merujuk pada tiga dimensi $\left(D_{1}, D_{2}, D_{3}\right)$ dari maqâshid al-syarîah. Sementara E adalah elemen. $E_{1}$, $E_{2}$, dan $E_{3}$ merujuk elemen-elemen dari masing-masing dimensi sebagaimana pada Tabel 2 sebelumnya. Dengan demikian, nilai indeks dari masing-masing dimensi adalah nilai komposit dari masing-masing elemen.

Setelah menemukan nilai komposit indeks dari masing-masing dimensi $\left(\mathrm{D}_{1 \text { (pendidikan) }}, \mathrm{D}_{2 \text { (keadilan) }}\right.$,

\footnotetext{
${ }^{21}$ Hendrie Anto, "Introducing an Islamic Human Development Index (I-HDI) to Measure Development in OIC Countries," Islamic Economic Studies Vol. 19, No. 2, 2011, h. 69-95.

${ }^{22}$ Herni Ali dan Ali Rama, "Peringkat Kinerja Lembaga Keuangan Syariah Berdasarkan Maqashid Syariah" Dialog Vol. 39, No. 2, 2016, h. 139-154.

${ }^{23}$ Omar Mustafa dan A. Dzuljastri Razak, "The Performance Measures of Islamic Banking Based on the Maqashid Framework," pada IIUM International Accounting Conference, 2008, h. 1-17.
}

$\left.\mathrm{D}_{3(\text { kesejahteraan) }}\right)$, nilai indeks maqâshid al-syarî̀ah selanjutnya dihitung dengan menggunakan metode rata-rata hitung. Adapun formulanya adalah sebagai berikut:

Indeks $\mathrm{MS}_{\text {(maqâshid al-syarîah) }}=1 / 3\left(D_{1}+D_{2}+D_{3}\right) \ldots \ldots$ (5)

Dengan demikian, indeks maqâshid alsyarîah adalah nilai komposit dari tiga dimensi utama, yaitu pendidikan $\left(D_{1}\right)$, keadilan $\left(D_{2}\right)$ dan kesejahteraan $\left(D_{3}\right)$.

Setelah menemukan nilai indeks maqâshid al-syarî̀ah untuk masing-masing bank syariah, analisis deskriptif dan komparasi serta korelasi dilakukan dalam penelitian. Analisis deskriptif digunakan untuk menguraikan dan menjelaskan nilai capaian atau kinerja masing-masing bank syariah yang diteliti yang direpresentasikan oleh nilai indeks maqâshid al-syarî̀ah. Selain itu, analisis deskriptif dilakukan untuk menjelaskan kondisi bank syariah berdasarkan pada data-data sekunder yang digunakan.

Selanjutnya, analisis komparasi antara bank syariah dilakukan untuk membandingkan bank mana yang menempati peringkat pertama dalam indeks atau dengan kata lain skor tertinggi dalam pencapaian tujuan maqâshid al-syarî̀ah. Analisis korelasi antara sejumlah variabel seperti jumlah aset dan profitabilitas dengan nilai indeks maqâshid al-syarîaah dilakukan untuk melihat sejauh mana hubungan variabel tersebut terhadap nilai skor indeks. Misalnya, apakah ada korelasi antara jumlah aset yang dimiliki oleh bank syariah dengan kinerja indeks maqâshid al-syarî̀ah -nya.

\section{Hasil dan Analisis}

\section{Analisis Deskripsi Aset, Profitabilitas dan Indeks Maqâshid al-syarîah Perbankan Syariah di Asia Tenggara}

Bagian ini menganalisis jumlah aset dan tingkat profitabilitas masing-masing bank syariah di Asia Tenggara. Tingkat profitabilitas yang dimaksud dalam penelitian ini direpresentasikan oleh rasio Return on Asset (ROA). ROA merupakan rasio dari pendapatan bersih bank syariah terhadap total aset yang dimiliki. Selain itu, nilai indeks maqâshid al-syarî̀ah masing-masing bank syariah juga ditampilkan. Skor indeks diartikan sebagai nilai rata-rata hitung (lihat persamaan 4) dari ketiga dimensi utama, yaitu pendidikan individu 
(ta'dîb al-fard), mewujudkan keadilan (iqâmah al-'adl) dan mendorong kesejahteraan (jalb almaslâhah). Skala indeks antara 1 sampai 100. Artinya, bank syariah yang memiliki nilai indeks tertinggi berarti memiliki kinerja tertinggi dalam total pencapaian dimensi-dimensi maqâshid alsyarîah.

\section{Indonesia}

Pada tahun 2013-2015 tercatat bahwa rata-rata aset perbankan syariah yang di Indonesia sekitar Rp 194 Triliun. Jumlah aset untuk masing-masing bank syariah di Indonesia memiliki perbedaan yang cukup signifikan. Berdasarkan Grafik 1 Bank Mandiri Syariah (BSM) dan Bank Muamalat Indonesia (BMI) merupakan bank syariah terbesar di Indonesia jika dilihat dari segi jumlah aset yang dimilikinya, yaitu masing-masing Rp 67.092 triliun dan Rp 58.093 triliun. Selain kedua bank syariah tersebut BRI syariah dan BNI syariah juga memiliki jumlah aset yang cukup signifikan dengan jumlah masing-masing adalah Rp 20.658 triliun dan Rp 19.072 triliun.

Sementara bank syariah lainnya, seperti Bank Mega Syariah, Bank Victoria Syariah, Bank Panin Syariah, Bank Bukopin Syariah, Maybank Syariah, BCA Syariah, dan BJB Syariah memiliki jumlah aset di bawah Rp 10 triliun. Bank victoria Syariah dan BCA Syariah adalah bank syariah yang memiliki jumlah aset terendah, yaitu Rp 1.380 triliun dan Rp 2.130 triliun.

Grafik 1: Aset Bank Umum Syariah Indonesia

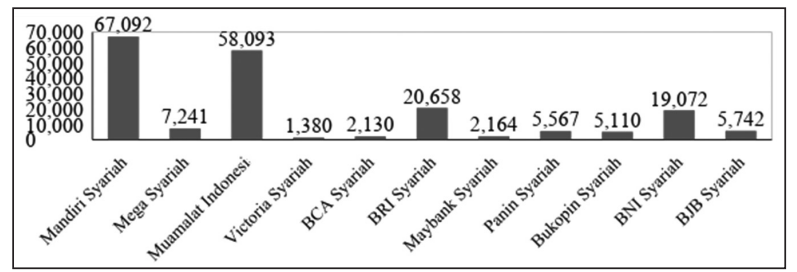

Sumber: Data diolah

Tingkat profitabilitas bank syariah di Indonesia pada tahun 2013-2015 bervariasi. Tingkat profitabilitas untuk masing-masing bank syariah di Indonesia disajikan pada Grafik 2. Bank BNI Syariah dan Mega syariah memiliki kinerja ratarata ROA tertinggi di antara Bank Syariah lainnya selama tahun 2013-2015. Rasio ROA masing-masing adalah $0,89 \%$ dan 0,82\%. Rasio ini menunjukkan bahwa bank BNI Syariah dan Mega Syariah mampu mengelola seluruh aset yang dimiliki untuk menghasilkan pendapatan bersih. Sementara bank BCA Syariah dan Mandiri Syariah hanya meraih $0,77 \%$ dan $0,50 \%$ rasio ROA. Bank umum syariah lainnya, seperti bank BCA Syariah, BSM, $B M I$ dan lainnya memiliki kinerja yang rendah jika dilihat dari segi tingkat rasio ROA. Masingmasing BUS tersebut memiliki tingkat ROA di bawah 0,50\%. Bahkan bank Victoria Syariah pada tahun 2013-2015 memiliki kinerja negatif, yaitu dengan tingkat rasio minus sebesar 0,95\%. ini menunjukkan bahwa pada periode tersebut, bank Victoria Syariah mengalami kerugian, yaitu biaya yang dikeluarkan lebih besar dibandingkan dengan pendapatan yang diterima. Temuan ini secara keseluruhan menunjukkan bahwa tidak terdapat korelasi positif bahwa tingkat aset yang besar akan mendorong tingkat profitabilitas (ROA) juga yang tinggi. Justru sebaliknya, bank syariah yang asetnya relatif rendah justru memiliki kinerja ROA yang lebih tinggi. Hal ini dapat dilihat secara detail pada Grafik 2.

Grafik 2: ROA Bank Umum Syariah Indonesia

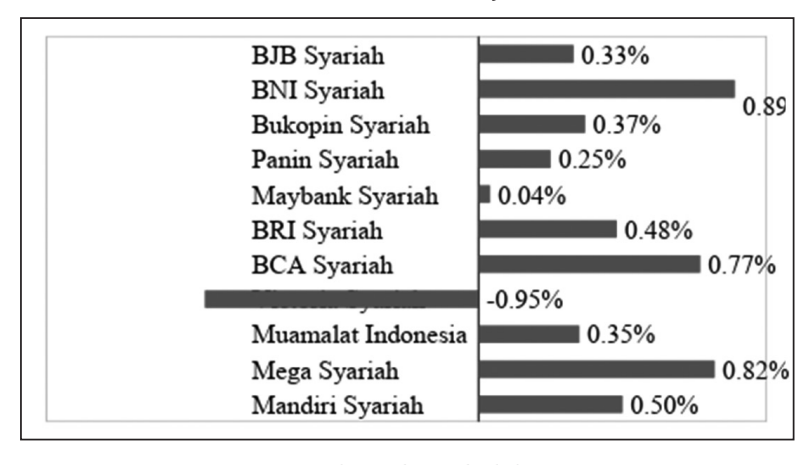

Sumber: data diolah

Grafik 3 menyajikan nilai indeks poin dari kinerja maqâshid al-syarîah masing-masing bank syariah yang ada di Indonesia. Grafik tersebut menunjukkan bahwa bank BRI Syariah memiliki nilai skor indeks terbesar dalam kinerja maqâshid al-syarîah dibandingkan dengan bank syariah lainnya yang ada di Indonesia. Adapun nilai indeks sebanyak 75,35 poin. Nilai skor ini lebih tinggi 13 poin dari indeks bank Panin Syariah dengan skor indeks sebesar 62,53 poin. Dengan demikian, dapat dikatakan bahwa kedua bank tersebut, yaitu bank BRI Syariah dan bank Panin Syariah menjadi peringkat pertama dan 
kedua dalam pencapaian kinerja bank syariah berdasarkan pendekatan maqâshid al-syarî̀ah. Jika dibandingkan dengan nilai indeks bank syariah lainnya, terdapat selisih sebesar 1 poin dengan peringkat ketiga selanjutnya yang ditempati oleh bank Muamalat Indonesia dengan nilai skor sebanyak 45 poin. Sementara peringkat selanjutnya adalah bank BNI Syariah sebesar 58,99 poin, dan Bukopin Syariah sebesar 51,11 poin. Adapun nilai skor indeks maqâshid alsyarîah untuk bank Mandiri Syariah, BCA Syariah, BJB Syariah, Victoria Syariah, Mega Syariah, dan Maybank Syariah berada di nilai skor indeks antara 20-40 poin.

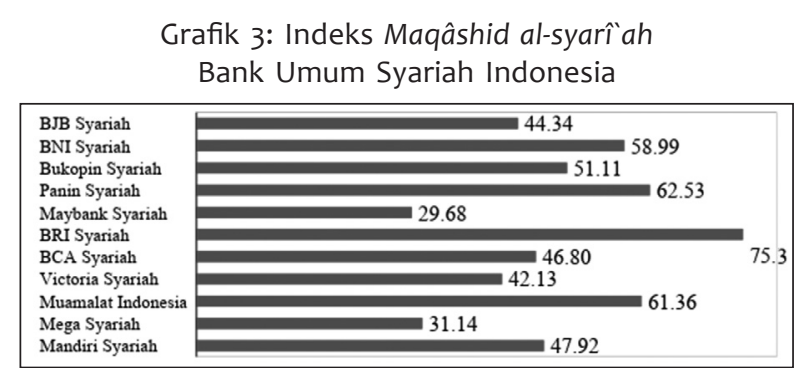

Sumber: Data diolah

Temuan penelitian yang cukup mengagetkan adalah nilai skor indeks bank Mandiri Syariah sebagai bank syariah terbesar di Indonesia dari segi ukuran kepemilikan aset (lihat Grafik 1) justru menempati peringkat terendah (ke-6) dengan nilai 47,92 poin. Dengan demikian, dapat disimpulkan bahwa nilai aset yang besar yang dimiliki oleh suatu bank syariah tidak menjadi jaminan kinerja maqâshid al-syarî̀ah yang tinggi. Selanjutnya, bank Maybank Syariah menempati peringkat terendah dalam kinerja maqâshid alsyarîah dengan nilai indeks hanya 29,68 poin. Hasil ini menunjukkan bahwa bank Maybank Syariah secara keseluruhan memiliki nilai kinerja yang buruk dalam pencapaian ketiga dimensi dari tujuan syariah, yaitu pendidikan individu (ta'dîb al-fard), mewujudkan keadilan (iqâmah al-'adl) dan mendorong kesejahteraan (jalb al-maslâhah).

\section{Malaysia}

Pada tahun 2013-2015 tercatat bahwa ratarata aset perbankan syariah di Malaysia sekitar RM 287 Triliun. Jumlah aset untuk masing-masing bank syariah di Malaysia memiliki perbedaan yang cukup signifikan. Berdasarkan Grafik 4 Bank CIMB
Islamic Bank Berhard dan Bank Islam Malaysia Berhard merupakan bank syariah terbesar di Malaysia jika dilihat dari segi jumlah aset yang dimilikinya, yaitu masing-masing RM 63.730 triliun dan RM 46.144 triliun. Selain kedua bank syariah tersebut RHB Islamic Bank Berhard dan AM Islamic Bank Berhard juga memiliki jumlah aset yang cukup signifikan dengan jumlah masingmasing adalah RM 36.440 triliun dan RM 35.914 triliun.

Sementara bank syariah lainnya, seperti Hong Leong Islamic Bank Berhard sebesar RM 22.268 triliun, Bank Mualamat Malaysia RM 21.197 triliun, HSBC Amanah Malaysia Berhard RM 16.758 triliun, Affin Islamic Bank Berhard RM 12.813 triliun, dan OCBC Al-Amin Bank Berhard RM. 12.801 triliun. Sedangkan, Standard Chartered Saadiq Berhard, Al Rajhi Banking \& Investment Corporation (Malaysia) Berhard, dan Asian Finance Bank Berhard memiliki jumlah aset di bawah RM 10 triliun. Al Rajhi Banking \& Investment Corporation (Malaysia) Berhard dan Asian Finance Bank Berhard adalah bank syariah yang memiliki jumlah aset terendah, yaitu RM 7.113 triliun dan RM 2.773 triliun.

Grafik 4: Aset Bank Syariah di Malaysia

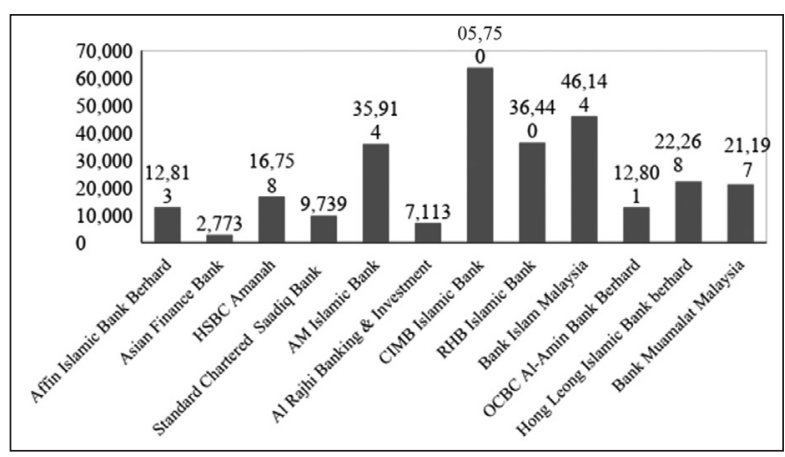

Sumber: Data diolah

Tingkat profitabilitas bank syariah di Malaysia pada tahun 2013-2015 bervariasi. Tingkat profitabilitas untuk masing-masing bank syariah di Malaysia disajikan pada Grafik 5. Bank Islam Malaysia Berhard dan CIMB Islamic Bank Berhard memiliki kinerja rata-rata ROA tertinggi di antara Bank Syariah lainnya selama tahun 2013-2015. Rasio ROA masing-masing adalah 1,09\% dan 0,99\%. Rasio ini menunjukkan bahwa Bank Islam Malaysia Berhard dan CIMB Islamic Bank Berhard mampu mengelola seluruh aset yang dimiliki untuk 
menghasilkan pendapatan bersih. Sementara Hong Leong Islamic Bank Berhard, OCBC Al-Amin Bank Berhard, HSBC Amanah Malaysia Berhard, AM Islamic Bank Berhard, dan Bank Muamalat Malaysia Berhard hanya meraih 0,98\%, 0,82\%, 0,81\%, 0,71\%, dan 0,63\% rasio ROA. Bank syariah lainnya, seperti RHB Islamic Bank Berhard, Affin Islamic Bank Berhard, Asian Finance Bank Berhard, Standard Chartered Saadiq Bank Berhard, Al Rajhi Banking \& Investment (Malaysia) Berhard memiliki kinerja yang rendah jika dilihat dari segi tingkat rasio ROA. Masing-masing bank syariah tersebut memiliki tingkat ROA di bawah $60 \%$. Temuan ini secara keseluruhan menunjukkan bahwa tidak terdapat korelasi positif bahwa tingkat aset yang besar akan mendorong tingkat profitabilitas (ROA) juga yang tinggi. Justru sebaliknya, bank syariah yang asetnya relatif rendah justru memiliki kinerja ROA yang lebih tinggi. Hal ini dapat dilihat secara detail pada Grafik 5.

Grafik 5: ROA Bank Syariah di Malaysia

\begin{tabular}{|c|c|}
\hline $\begin{array}{l}\text { Bank Muamalat Malaysia } \\
\text { Hong Leong Islamic Bank berhard } \\
\text { OCBC A1-Amin Bank Berhard } \\
\text { Bank Islam Malaysia } \\
\text { RHB Islamic Bank } \\
\text { CIMB Islamic Bank } \\
\text { Al Rajhi Banking \& Investment } \\
\text { AM Islamic Bank } \\
\text { Standard Chartered Saadiq Bank } \\
\text { HSBC Amanah } \\
\text { Asian Finance Bank } \\
\text { Affin Islamic Bank Berhard }\end{array}$ & 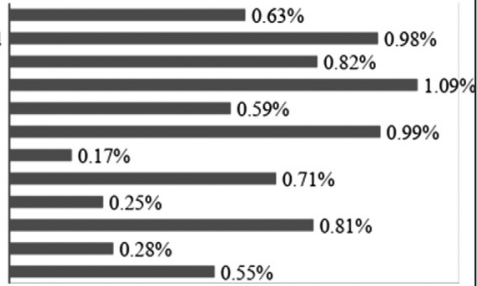 \\
\hline
\end{tabular}

Sumber: Data diolah

Grafik 6 menyajikan nilai indeks dari kinerja maqâshid al-syarîaah masing-masing bank syariah yang ada di Malaysia. Berdasarkan grafik tersebut ditemukan bahwa bank Affin Islamic Bank Berhard memiliki nilai skor indeks terbesar dalam kinerja maqâshid al-syarî̀ah dibandingkan dengan bank syariah lainnya yang ada di Malaysia. Adapun nilai indeks sebanyak 56,14 poin. Nilai skor ini lebih tinggi 7 poin dari indeks Asian Finance Bank Berhard dengan skor indeks sebesar 49,03 poin. Dengan demikian, dapat dikatakan bahwa kedua bank tersebut, yaitu bank Affin Islamic Bank Berhard dan Asian Finance Bank Berhard menjadi peringkat pertama dan kedua dalam pencapaian kinerja bank syariah berdasarkan pendekatan maqâshid al-syarîah . Jika dibandingkan dengan nilai indeks bank syariah lainnya, terdapat selisih sebesar 7 poin dengan peringkat ketiga selanjutnya yang ditempati oleh bank RHB Islamic Bank Berhard dengan nilai skor sebanyak 42,31 poin. Sementara peringkat selanjutnya adalah bank RHB Islamic Bank Berhard dan Al Rajhi Banking \& Investment (Malaysia) Berhard sebesar 42,31 poin dan sebesar 40,64 poin. Adapun nilai skor indeks maqâshid al-syarî̀ah untuk bank HSBC Amanah Malaysia Berhard, Bank Muamalat Malaysia, CIMB Islamic Bank Berhard, HSBC Amanah Malaysia Berhard, OCBC Al-Amin bank Berhard, Bank Islam Malaysia Berhard, Standard Chartered Saadiq Bank Berhard, AM Islamic Bank Berhard, dan Hong Leong Islamic Bank Berhard berada di nilai skor indeks antara 20-40 poin.

Grafik 6: Indeks Maqâshid al-syarîaah Bank Syariah di Malaysia

\begin{tabular}{|c|c|}
\hline $\begin{array}{l}\text { Bank Muamalat Malaysia } \\
\text { Hong Leong Islamic Bank berhard } \\
\text { OCBC Al-Amin Bank Berhard } \\
\text { Bank Islam Malaysia } \\
\text { RHB Islamic Bank } \\
\text { CIMB Islamic Bank } \\
\text { A1 Rajhi Banking \& Ivestment } \\
\text { AM Islamic Bank } \\
\text { Standard Chartered Saadiq Bank } \\
\text { HSBC Amanah } \\
\text { Asian Finance Bank } \\
\text { Affin Islamic Bank Berhard }\end{array}$ & 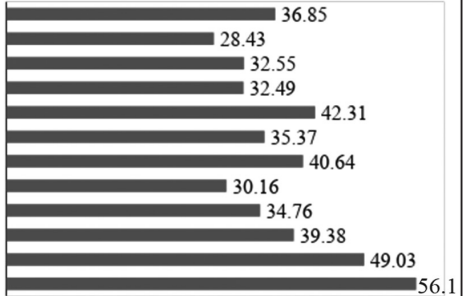 \\
\hline
\end{tabular}

Temuan penelitian yang yang hampir sama dengan perbankan syariah yang berada di Indonesia, bank syariah di Malaysia bahwa nilai skor indeks bank CIMB Islamic Bank Berhard sebagai bank syariah terbesar di Malaysia dari segi ukuran kepemilikan aset (lihat Grafik 4) hanya menempati peringkat terendah ke-6 dengan nilai 35,37 poin. Selanjutnya, bank Hong Leong Islamic Bank Berhard menempati peringkat terendah dalam kinerja maqâshid al-syarî̀ah dengan nilai indeks hanya 28,43 poin. Hasil ini menunjukkan bahwa bank Hong Leong Islamic Bank Berhard secara keseluruhan memiliki nilai kinerja yang buruk dalam pencapaian ketiga dimensi dari tujuan syariah.

\section{Singapura}

Pada penelitian ini hanya memasukkan dua bank syariah yang telah beroperasi di Singapura. Rata-rata aset perbankan syariah di Singapura sekitar SGD 59 Triliun pada periode 2013-2015. Jumlah aset untuk masing-masing bank syariah di Singapura memiliki perbedaan yang cukup 
signifikan. Berdasarkan Grafik 7 Bank Maybank Islamic Bank merupakan bank syariah terbesar di Singapura jika dilihat dari segi jumlah aset yang dimilikinya, yaitu SGD 47.638 triliun. Selain itu bank Noor Islamic Bank juga memiliki jumlah aset yang cukup signifikan dengan jumlah asetnya sebesar SGD 11.551 triliun.

Grafik 7: Aset Bank Syariah di Singapura

\begin{tabular}{|c|c|c|c|c|c|c|}
\hline \multirow{3}{*}{$\begin{array}{l}\text { Maybank Islamic Bank } \\
\text { Noor Islamic Bank }\end{array}$} & \multicolumn{6}{|c|}{47,638} \\
\hline & & 551 & & & & \\
\hline & 10,000 & 20,000 & 30,000 & 40,000 & 50,000 & 60,000 \\
\hline
\end{tabular}

Sementara itu, dari segi tingkat profitabilitas sebagaimana di tampilkan pada Grafik 7, Bank Noor Islamic Bank memiliki kinerja rata-rata ROA tertinggi di antara Bank Syariah lainnya selama tahun 2013-2015. Rasio ROA Noor Islamic Bank adalah 13,74\%. Rasio ini menunjukkan bahwa Bank Noor Islamic Bank mampu mengelola seluruh aset yang dimiliki untuk menghasilkan pendapatan bersih. Sementara Maybank Islamic Bank hanya meraih 2,34\% rasio ROA. Bank Maybank Islamic Bank memiliki kinerja yang rendah jika dilihat dari segi tingkat rasio ROA. Temuan ini secara keseluruhan menunjukkan bahwa tidak terdapat korelasi positif bahwa tingkat aset yang besar akan mendorong tingkat profitabilitas (ROA) juga yang tinggi. Justru sebaliknya, bank syariah yang asetnya relatif rendah justru memiliki kinerja ROA yang lebih tinggi. Hal ini dapat dilihat secara detail pada Grafik 4.8.

Grafik 8: ROA Bank Syariah di Singapura

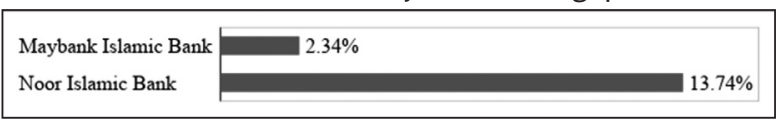

Sumber: Data diolah

Selanjutnya, Grafik 9 menyajikan bahwa bank Maybank Islamic Bank memiliki nilai indeks terbesar dalam kinerja maqâshid al-syarîah dibandingkan dengan bank Noor Islamic Bank. Adapun nilai indeks Bank Maybank Islamic Bank sebanyak 51,88 poin. Nilai skor ini lebih tinggi 17 poin dari indeks Maybank Islamic Bank dengan skor indeks sebesar 34,07 poin. Kinerja indeks tersebut menunjukkan hubungan terbalik dengan jumlah aset yang dimiliki oleh bank syariah di
Malaysia. Hal ini terlihat pada bank Maybank Islamic Bank sebagai bank terbesar dilihat dari segi aset justru menempati peringkat terendah dengan nilai 34,07 poin.

Grafik 9: Indeks Maqâshid al-syarî̀ah Bank Syariah di Singapura

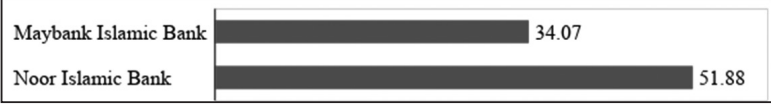

Sumber: Data diolah

\section{Brunei Darussalam}

Penelitian ini hanya menggunakan satu bank syariah yang beroperasi di Brunei darussalam, yaitu Bank Islam Brunei Darussalam Berhard (BIBD). Nilai aset bank syariah tersebut antara periode 2013-2015 adalah sebesar $B \$ 6.799$. Sementara profitabilitas (ROA) pada tahun 2015 adalah sebesar 1,20\%.

Selanjutnya, kinerja maqâshid al-syarîah Bank Islam Brunei Darussalam Berhard (BIBD) berdasarkan konsep dan indikator yang dikembangkan dalam penelitian ini dapat dilihat pada Tabel 3.

Berdasarkan tabel 4.10, Bank Islam Brunei Darussalam Berhard tercatat mencapai skor indeks pada dimensi ini dengan nilai masingmasing sebesar 46,81 poin. Skor indeks ini menunjukkan bahwa bank tersebut memiliki rasio pada ROA dan investasi sektor riil terhadap total investasi. Nilai indeksnya hanya sebesar 38,99 poin. Dari nilai tersebut dikontribusikan utamanya oleh dimensi kesejahteraan sebesar 46,81 dan selanjutnya pendidikan sebesar 35,82.

Tabel 3: Indeks Maqâshid al-syarîah Bank Islam Brunei Darussalam Berhard Singapura

\begin{tabular}{|c|c|c|c|c|c|}
\hline No & $\begin{array}{c}\text { Bank } \\
\text { Syariah }\end{array}$ & $\begin{array}{l}\text { Pendidikan } \\
\text { Individu } \\
\text { (Ta'dîb } \\
\text { al-Fard) }\end{array}$ & $\begin{array}{l}\text { Mewujudkan } \\
\text { Keadilan } \\
\text { (Iqamah } \\
\text { al-'adl) }\end{array}$ & $\begin{array}{c}\text { Mendorong } \\
\text { Kesejahteraan } \\
\text { (Jalb al- } \\
\text { Maslahah) }\end{array}$ & $\begin{array}{c}\text { Indeks } \\
\text { Maqashid } \\
\text { Syariah }\end{array}$ \\
\hline & & $1 / 3$ & $1 / 3$ & $1 / 3$ & \\
\hline 1 & $\begin{array}{l}\text { Bank Islam } \\
\text { Brunei } \\
\text { Darussalam } \\
\text { Berhard } \\
\text { (BIBD) }\end{array}$ & 35,82 & 34,33 & 46,81 & 38,99 \\
\hline
\end{tabular}

Sumber: Data diolah

\section{Filipina}

Sebagai negara dengan penduduk mayoritas non muslim jumlah bank syariah yang beroperasi di Filipina sangat minim. Hal ini dapat dipahami 
karenan kurangnya permintaan pasar sehingga perbankan syariah tidak bisa berkembang dengan pesat seperti di Malaysia dan Indonesia. Dengan rendahnya populasi muslim tentunya berdampak juga terhadap kinerja perbankan syariah di negara tersebut.

Penelitian ini hanya menggunakan bank Investasi Islam Al Amanah Filipina dikarenakan bank tersebut merupakan satu-satunya bank syariah yang beroperasi di negara tersebut. Adapun jumlah aset bank Investasi Islam Al Amanah Filipina pada periode 2015 sebesar P 720.178 triliun. Selain itu, bank syariah di Filipina tersebut memiliki kinerja keuangan yang relatif buruk, yaitu dengan tingkat rasio minus sebesar 45,27\%. Ini menunjukkan bahwa pada periode tersebut, bank bank Investasi Islam Al Amanah Filipina memiliki biaya yang dikeluarkan jauh lebih besar dibandingkan dengan pendapatan yang diterima.

Jumlah aset yang rendah dan diperburuk dengan kinerja profitabilitas yang minus tentunya berdampak juga terhadap kinerja indeks maqâshid al-syarî̀ah. Tabel 4 menyajikan hasil perhitungan nilai indeks maqâshid al-syarîa ah dari bank syariah di Filipina. Tabel tersebut menunjukkan bahkan nilai keseluruhan indeksnya hanya sebesar 20,17 poin. Bank syariah di Filipina tersebut lebih banyak menonjol pada aspek kesejahteraan dibandingkan dengan dua aspek dari maqâshid al-syarîah lainnya yang dikembangkan dalam penelitian ini.

Tabel 4. Skor Indeks Maqâshid al-syarî̀ah Bank AlAmanah Islamic Investment Bank of Philippines

\begin{tabular}{cccccc}
\hline No & $\begin{array}{c}\text { Bank } \\
\text { Syariah }\end{array}$ & $\begin{array}{c}\text { Pendidikan } \\
\text { Individu } \\
\text { (Ta'dîb } \\
\text { al-Fard) }\end{array}$ & $\begin{array}{c}\text { Mewujudkan } \\
\text { Keadilan } \\
\text { (Iqamah al- } \\
\text { 'adl) }\end{array}$ & $\begin{array}{c}\text { Mendorong } \\
\text { Kesejahteraan } \\
\text { (Jalb al- } \\
\text { Maslahah) }\end{array}$ & $\begin{array}{c}\text { Indeks } \\
\text { Maqashid } \\
\text { Syariah }\end{array}$ \\
\hline 1 & $1 / 3$ & $1 / 3$ & $1 / 3$ & \\
\hline & $\begin{array}{c}\text { Bank } \\
\text { Investasi } \\
\text { Islam Al } \\
\text { Amanah } \\
\text { Filipinan }\end{array}$ & 20,01 & 0,00 & 40,50 & 20,17 \\
\hline
\end{tabular}

Sumber: Data diolah

\section{Thailand}

Kondisi perbankan syariah di Thailand tidak jauh berbeda dengan kondisi perbankan syariah di Filipina. Hal ini disebabkan kedua negara tersebut memiliki jumlah penduduk Muslim yang sangat minim. Sebagaimana diketahui, jumlah penduduk muslim menjadi pendorong utama terjadinya peningkatan permintaan terhadap produk dan layanan perbankan syariah.

Akibatnya, kinerja perbankan syariah di Thailand juga tidak lebih baik dibandingkan dengan negara-negara berpenduduk mayoritas muslim seperti Indonesia dan Malaysia di Asia Tenggara. Bank Islam Thailand (Islamic Bank of Thailand) merupakan satu-satunya bank syariah yang beroperasi di Thailand. Jumlah aset bank syariahnya hanya sekitar Baht 105.975 triliun dengan rasio Kinerja ROA sebesar -3,59\%. Adapun kinerja indeks maqâshid al-syarîah dapat dilihat pada Tabel 5. Nilai indeks maqâshid al-syarî̀ah hanya sebesar 33,26 poin yang kinerja masingmasing dimensi dari indeks relatif sama sekitar 30 poin.

Tabel 5: Skor Indeks Maqâshid al-syarîah Bank Islamic Bank of Thailand

\begin{tabular}{cccccc}
\hline No & $\begin{array}{c}\text { Bank } \\
\text { Syariah }\end{array}$ & $\begin{array}{c}\text { Pendidikan } \\
\text { Individu } \\
\text { (Ta'dîb } \\
\text { al-Fard) }\end{array}$ & $\begin{array}{c}\text { Mewujudkan } \\
\text { Keadilan } \\
\text { (Iqamah } \\
\text { al-'adl) }\end{array}$ & $\begin{array}{c}\text { Mendorong } \\
\text { Kesejahteraan } \\
\text { (Jalb al- } \\
\text { Maslahah) }\end{array}$ & $\begin{array}{c}\text { Indeks } \\
\text { Maqashid } \\
\text { Syariah }\end{array}$ \\
\hline 1 & $1 / 3$ & $1 / 3$ & $1 / 3$ & \\
\hline & $\begin{array}{c}\text { Islamic } \\
\text { Bank of } \\
\text { Thailand }\end{array}$ & 29,67 & 31,22 & 38,89 & 33,26 \\
\hline
\end{tabular}

Sumber: Data diolah

\section{Peringkat Kinerja Maqâshid al-syarîaah Perbankan Syariah di Asia Tenggara}

Sebagaimana dijelaskan sebelumnya bahwa indeks maqâshid al-syarîah merupakan nilai rata-rata hitung atau komposit indek dari tiga dimensi utama dari maqâshid al-syarî̀ah yang dikembangkan dalam penelitian ini, yaitu peningkatan pendidikan, penegakan keadilan dan penciptaan kesejahteraan. Dengan demikian, skor indeks merepresentasikan kinerja dari bankbank syariah yang diteliti dalam hal penguatan ketiga dimensi maqâshid al-syarîah tersebut. Bank syariah yang memiliki indeks tinggi berarti berkinerja tertinggi dalam hal penguatan dimensi maqâshid al-syarîaah dan begitupula sebaliknya. Nilai indeks antara 1-100.

Grafik 10 menyajikan skor indeks maqâshid al-syarîah seluruh bank syariah yang diteliti di negara Asia Tenggara. Bank syariah yang memiliki 
nilai indeks tertinggi berarti memiliki kinerja tertinggi dalam total pencapaian dimensi-dimensi maqâshid al-syarîaah

Grafik 10: Peringkat Kinerja Maqâshid al-syarîah Perbankan Syariah di Asia Tenggara

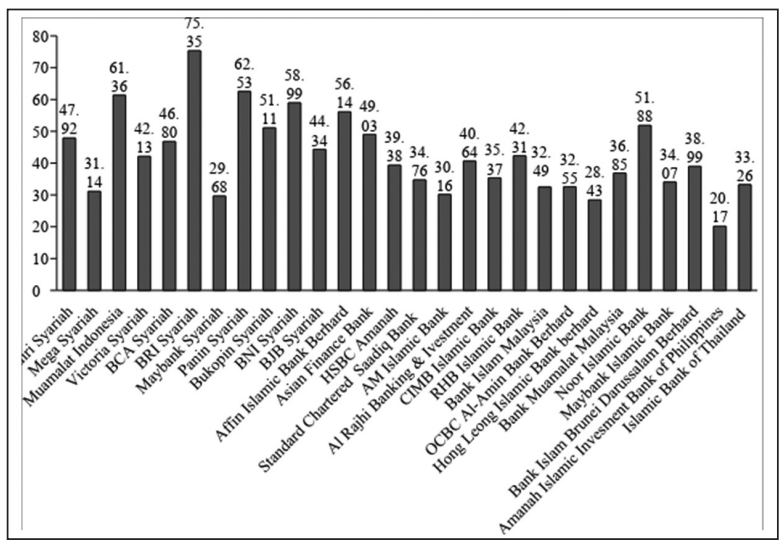

Sumber: data diolah

Berdasarkan Grafik 10 ditemukan bahwa perbankan syariah di Asia Tenggara yang memiliki kinerja maqâshid al-syarî̀ah yang paling tinggi adalah perbankan syariah yang berada di Indonesia. Bank BRI Syariah mencapai nilai skor tertinggi dalam pengukuran kinerja indeks maqâshid al-syarî̀ah dengan nilai indeks sebesar 75,35 poin. Bank syariah lainnya yang memiliki kinerja indeks maqâshid al-syarîah yang tinggi, yaitu di atas 50 poin ditempati secara berturutturut oleh bank Panin Syariah $(62,53)$, Muamalat Indonesia (61,36), BNI Syariah (58,99), Affin Islamic Bank Berhard $(56,14)$, Noor Islamic Bank $(51,88)$, dan Bukopin Syariah $(51,11)$. Sementara bank syariah lainnya di Asia Tenggara memiliki skor indeks di bawah 50 poin. Hasil indeks ini menunjukkan bahwa mayoritas bank syariah di Asia Tenggara memiliki kinerja indeks maqâshid al-syarîah yang rendah. Dengan kata lain bahwa keberadaan bank syariah dalam rangka untuk merealisasikan dari tujuan-tujuan syariah dalam hal ini memperkuat pendidikan individu, menegakkan keadilan dan menciptakan kesejahteraan masih jauh dari harapan. Seharusnya bank syariah yang memiliki visi untuk menjalankan ajaran-ajaran Islam dalam bidang keuangan dan perbankan tidak seharusnya hanya menitikberatkan pada aspek kepatuhan syariah dari produk dan operasionalnya semata tetapi semestinya memperhatikan aspek-aspek substansi yaitu penguatan kualitas SDM dan kesejahteraan dan penciptaan keadilan ekonomi.

\section{Uji Korelasi Indeks Maqâshid al-syarîah dengan Aset dan Tingkat Profitabilitas}

Uji korelasi dilakukan untuk melihat sejauh mana hubungan antara indeks maqâshid al-syarîah dengan jumlah aset dan tingkat profitabilitas perbankan syariah. Hasil uji korelasi ditampilkan pada Tabel 6. Tabel tersebut menunjukkan bahwa tidak terdapat korelasi kuat antara jumlah aset bank syariah dengan kinerja indeks maqâshid al-syarîah. Ini menunjukkan bahwa jumlah aset bank syariah tidak menjadi penentu kinerja indeks. Bank syariah yang memiliki jumlah aset yang besar tidak menjamin kinerja indeks maqâshid alsyarîa h yang tinggi. Sebaliknya, bank syariah yang beraset kecil boleh jadi memiliki kinerja indeks maqâshid al-syarîaah yang lebih tinggi. Hasil uji korelasi ini sejalan dengan temuan antara jumlah aset dan kinerja indeks di masing-masing negara (bank syariah) yang telah diuraikan sebelumnya.

Sebaliknya, terdapat korelasi tinggi, sekitar 98\% antara tingkat profitabilitas bank syariah dengan kinerja indeks maqâshid al-syarî̀ah-nya. Bank syariah yang profitabilitasnya tinggi juga akan memiliki tingkat kinerja indeks maqâshid al-syarîah yang tinggi pula dan begitu pula sebaliknya. Temuan ini yang dapat menjelaskan kenapa bank-bank syariah yang beraset terbesar justru berkinerja indeks maqâshid al-syarîah yang rendah, hal ini sebagiannya disebabkan oleh umumnya bank syariah tersebut memiliki tingkat profitabilitas rendah pada periode penelitian.

Tabel 6: Korelasi Indeks Maqâshid al-syarîah dengan Tingkat Profitabilitas

\begin{tabular}{|c|c|c|c|}
\hline & Indeks MS & Aset & ROA \\
\hline Indeks MS & 1,00 & 0,47 & 0,98 \\
\hline Aset & 0,47 & 1,00 & 0,00 \\
\hline ROA & 0,98 & 0,00 & 1,00 \\
\hline
\end{tabular}

Sumber: Data diolah

\section{Penutup}

Penelitian ini menemukan bahwa dari 28 bank syariah yang diteliti yang tersebar di enam negara Asia Tenggara (Indonesia, Malaysia, Brunei Darussalam, Thailand, Singapura dan 
Filipina) menunjukkan bahwa hanya terdapat tujuh bank syariah yang memiliki skor indeks di atas 50 poin, sementara mayoritas sisanya di bawah 50 poin. Nilai indeks ini menggambarkan bahwa secara keseluruhan perbankan syariah di Asia Tenggara belum menjadikan substansi visi Islam yang direpresentasikan oleh tujuan-tujuan syariah yang ingin dicapai dalam bidang ekonomi sebagai tujuan utama, yaitu penguatan kualitas SDM melalui pendidikan dan kesejahteraan dan penegakan keadilan ekonomi. Hal ini juga menunjukkan bahwa perbankan syariah umumnya masih dijalankan berdasarkan pada visi konvensional meskipun sudah beroperasi sesuai dengan prinsip syariah atau sharia compliance.

Selain itu, BRI syariah yang beroperasi di Indonesia berkinerja tertinggi dalam indeks maqâshid al-syarîa ah yang juga selanjutnya diikuti oleh Panin Syariah dan Muamalat Indonesia. Dengan demikian, perbankan syariah di Indonesia leading dalam hal kinerja indeks maqâshid alsyarîah di Asia Tenggara. Sebaliknya, negaranegara yang berpenduduk muslim minoritas seperti Thailand dan Filipina serta Singapura relatif rendah dalam kinerja indeks maqâshid al-syarîah.

\section{Pustaka Acuan}

Ali, Herni HT dan Ali Rama,"Peringkat Kinerja Lembaga Keuangan Syariah Berdasarkan Maqashid Syariah," Dialog, Vol. 39, No. 2, 2016. Anto, Hendrie, "Introducing an Islamic Human Development Index (I-HDI) to Measure Development in OIC Countries," Islamic Economic Studies Vol. 19, No. 2, 2011.

Chapra, Umar, The Islamic Vision of Development in the Light of Maqasid Al-Shariah, IDB, 2008.

Dusuki, Asyraf Wajdi Dusuki dan Nurdianawati Irwani Abdullah, "Why Do Malaysian Customers Patronise Islamic Banks?," International Journal of Bank Marketing, Vol. 25 No. 3, 2007.

, "Maslahah and Corporate Social Responsibility," The American Journal of Islamic Social Science, Vol. 24, No. 1, 2005.

IFSB, Islamic Financial Service Industry Stability Report 2015
Irwani, Asyraf Wajdi Dusuki dan Abdullah Nurdianawati, "Maslahah and Corporate Social Responsibility," The American Journal of Islamic Social Science, Vol. 24, No. 1, 2005. Laldin, Mohamad Akram dan Hafas Furqani, "Developing Islamic Finance in the Framework of Maqasid Al-Shari'ah," International Journal of Islamic and Middle Eastern Finance and Management, Vol. 6 No. 4, 2013.

Mustafa, Omar dan A. Dzuljastri Razak, "The Performance Measures of Islamic Banking Based on the Maqashid Framework," pada IIUM International Accounting Conference, 2008.

Obaidullah, Mohamad "Rating of Islamic Financial Institutions Some Methodological Suggestions," Working Paper, IRTI Jedah, 2005.

Qardhawi, Yusuf, Figh Maqashid Syariah, Jakarta: Pustaka al-Kautsar, 2007.

Rama, Ali dan Makhlani, "Pembangunan Ekonomi Dalam Tinjauan Maqashid Syariah," Dialog, Vol. 1, No. 1, 2013.

Rama, Ali dan Meliawati,“Analisis Determinan Pengungkapan Islamic Social Reporting: Studi Kasus Bank Umum Syariah Di Indonesia," EQUILIBRIUM: Jurnal Ekonomi Syariah, Vol. 2, No. 1, 2014.

Rama, Ali, "Analisis Deskriptif Perkembangan Perbankan Syariah Di Asia Tenggara," Journal of Tauhidinomics, Vol. 1 No. 1, 2015. , "Analisis Kerangka Regulasi Model Shariah Governance," Journal of Islamic Economics Lariba, Vol. 1 No. 1, 2015.

, "Analisis Sistem Tata Kelola Syariah Bagi Perbankan Syariah Di Indonesia Dan Malaysia," Jurnal Bimas Islam, Vol. 8 No. 1, 2015.

, "Potensi Ekonomi Syariah Global," Republika, tanggal 24 November 2014.

Shidiq, Ghofar, “Teori Maqashid Al-Syari'ah Dalam Hukum Islam," Sultan Agung, Vol. XIV, No. 1, 2009.

Zaharah, Abu, Ushulul Fiqh, Mesir: Dar el-Fikri al Arabi, 1958.

Zuhaili, Wahbah al-, Ushul Al-Figh Al-Islami, Beirut: Dar al-Fikr, 1986. 